\title{
A Shadow of Orthodoxy? An Epistemology of British Hydropathy, 1840-1858
}

\author{
JAMES BRADLEY and MARGUERITE DUPREE*
}

\section{Hydropathy and its Historians}

During the 1820s Vincent Priessnitz established Gräfenberg ${ }^{1}$ as the first centre for hydropathy, his novel modification of water-based therapies. As word of the seemingly miraculous cure spread, spiralling numbers of patients journeyed from across Europe, and further afield, to place themselves under Priessnitz's care. ${ }^{2}$ It was not, however, until the early 1840s that hydropathy impinged upon the consciousness of Britain's medical practitioners and valetudinarians. While short reviews describing the new therapy appeared in the medical press in $1841,{ }^{3}$ it was Captain Claridge who was responsible for mobilizing British interest in the water cure. In 1842 he published an account of his experiences as a patient of Priessnitz, and followed this with a tireless lecture tour around the British Isles. ${ }^{4}$ His descriptions of hydropathy appealed to a public whose ardour remained undimmed for any therapy that promised relief from disease. The bulk of the medical practitioners were less convinced. Some reacted

* James Bradley, PhD, formerly Centre for the History of Medicine, University of Glasgow, currently International Centre for the History of Sport and Culture, De Montfort University, Leicester; Marguerite Dupree, DPhil, Centre for the History of Medicine, University of Glasgow, 5 University Gardens, Glasgow G12 8QQ.

We are grateful to the Wellcome Trust for the funding of two grants which supported the research and development of this article: the first was the project grant for 'The Enterprising Medical Entrepreneur: the Hydropathic Movement in Scotland, c. 1840-1940', with Drs Marguerite Dupree and Alastair Durie as cogrant holders (Ref. No. 045072); the second was the research fellowship awarded to Dr James Bradley for 'Water, Therapeutics and Disease' (Ref. No. 052978). The authors wish to thank Dr Alastair Durie for his contributions to the first project. We also would like to thank the anonymous referees and Professor W F Bynum for their constructive comments.

${ }^{1}$ There were many variant spellings of Gräfenberg. We use this variant in our text, but leave the original spelling in contemporary quotes unchanged. The current Czech spelling is Gräfenberk.

${ }^{2}$ Beginning in 1829 with 45 patients, the numbers rose steadily to 570 in 1837 and then dramatically to approximately 1,400 per year in 1839 , remaining at that level for at least three years. The majority of patients in 1840 came from central Europe, including Prussia (527), Austria (367), Hungary (137), Poland (128), Russia (94) and Galicia (93), but they also came from further away, including France (15), America, Sweden (7) and England (2). While the figures should be treated as indicators rather than actual numbers, they are not mere guesses, as visitors to the area had to report to the local police who provided the figures to contemporary authors. R T Claridge, Hydropathy; or, the cold water cure, London, J Madden, 1842, pp. 69, $70-1$.

${ }^{3}$ See review of Dr H Claessen's The truth and falsehood of the so-called cold water cure, in $\mathrm{Br}$. for. med. Rev., 1841, 12: 189-93; also the appendix in Edwin Lee, The principal baths of Germany considered with reference to their remedial efficacy in chronic disease, London, 2 vols, John Churchill, 1841, vol. 2.

${ }^{4}$ See Claridge, op. cit., note 2 above. 


\section{James Bradley and Marguerite Dupree}

facetiously. ${ }^{5}$ Others displayed outright hostility. ${ }^{6}$ Despite the profession's negative reaction, a few qualified practitioners risked professional and pecuniary ruin to develop their own hydropathic centres. ${ }^{7}$ Over twenty hydropathic institutions were created across Britain before 1860, attracting a large clientele including many eminent Victorians. ${ }^{8}$

This essay seeks to recast our understanding of hydropathy's relationship with medical orthodoxy during the turbid reform years, focusing primarily on the period before the Medical Act of 1858. The Act did not set the boundaries of legitimate practice in law nor did hydropathy cease to be practised and establishments opened after the Act, but hydropathy was new and at its most distinctive in the period before the Act. Historians have generally presented hydropathy as a system standing in direct opposition to orthodoxy. In establishing its oppositional credentials there has been a tendency to conflate its characteristics with other heterodox practices. Logie Barrow's cogent analysis of medical heresy during the 1840 s is typical. Initially he includes hydropathy in a long list of unorthodox therapies. ${ }^{9}$ As his argument unfolds, revealing the manifold layers of radical discourse underwriting these practices, hydropathy fades to the point of invisibility and is excluded from his concluding remarks. ${ }^{10}$ Barrow's omission is symptomatic of hydropathy's failure to sit comfortably in either the orthodox or heterodox camp. Nevertheless, because historians have made it stand four-square with other medical "heresies", it is pronounced guilty by association and is forced to acquire the features of an homogenized heterodoxy, particularly as a power opposing orthodox theory and practice. In this account an holistic vision was embedded in the core of all heterodox practices: each heterodoxy represented an explicit rejection of the orthodox attempt to erase the sick man from medical cosmology, focusing instead upon visible lesions in diseased organs. ${ }^{11}$ Furthermore, this denial of the ontological model of disease made heterodoxies particularly attractive to the radical and dissenting classes. ${ }^{12}$ Hydropathy thus represented was, like homœopathy and medical botany, no more nor less than a

\footnotetext{
${ }^{5}$ See Edinburgh med. J., 1842, 58: 155-86.

${ }^{6} \mathrm{See}$, for example, Lancet, 1841-2, i: 830-3; ii: 429-30, 489-91; 1842-3, i: 687; 1843-4, i: 610, 612; Prov. med. surg. J.,1843-4, 7: 52-4; 1843, 6: 393-5.

${ }^{7}$ Robin Price, 'Hydropathy in England, 1840-70', Med. Hist., 1981, 25: 269-80, pp. 273-8; Janet Browne, 'Spas and sensibilities: Darwin at Malvern', in Roy Porter (ed.), The medical history of waters and spas, Med. Hist. Supplement No. 10, London, Wellcome Institute for the History of Medicine, 1990, pp. 102-13, p. 106.

${ }^{8}$ Browne, op. cit., note 7 above, p. 102 fn. 4, lists 26 hydropathic institutions "in existence before 1850 ". The list is not entirely accurate. For example, it includes Cluny Hill, founded in
}

the mid-1860s while excluding Sir Arthur Clarke's Dublin establishment. New establishments also opened in the 1850 s, such as the Gilmorehill Hydropathic in Glasgow.

${ }^{9}$ Logie Barrow, 'Why were most medical heretics at their most confident around the 1840s? (The other side of mid-Victorian medicine)', in Roger French and Andrew Wear (eds), British medicine in an age of reform, London, Routledge, 1991 , pp. $165-85$, on p. 165.

${ }^{10}$ Ibid., p. 182.

${ }^{11} \mathrm{~N} D$ Jewson, 'The disappearance of the sick-man from medical cosmology, 1770-1870', Sociology, 1976, 10: 225-44.

${ }^{12} \mathrm{See}$, for example, Barrow, op. cit., note 9 above, p. 166, which notes all heresies were "holistic". 
"shadow of orthodoxy"-a "counter-hegemonic" resistance to the dominant mode of medical practice. ${ }^{13}$

The tendency of historians to flatten all unorthodoxies into the two-dimensional category of "heterodox" is understandable, not least because those contemporaries that discounted hydropathy linked it with other heterodox practices in a sweeping rhetoric of anti-quackery. In many respects, Barrow and others $d o$ accurately locate hydropathy's position upon the orthodox-heterodox axis. It was attractive to small dissenting sects, "quacks", advocates of temperance and abstinence, vegetarians, and anti-vaccinationists and vivisectionists. ${ }^{14}$ But these associations were part of a larger and more intricate mosaic of social and medical forces that shaped British hydropathy. As a number of scholars have demonstrated, the simple equation making a belief in the water cure equivalent to social and medical radicalism is not tenable under scrutiny. P S Brown, for example, hints at a conceptual gulf driven between the medically qualified and unqualified practitioners, and indicates that a difference between the two lay in theory not therapy. ${ }^{15}$ Kelvin Rees, too, sees a complex dynamic at work where hydropathy and hydropathists aped allopathy's theory of disease and physiology. ${ }^{16}$

Recently, historians of other heterodoxies during the period, such as mesmerism and homœopathy, have pointed to the complexities and fluidity of medical ideas and practice and, in the case of homœopathy, to differences among countries. Alison Winter, for example, has stressed the highly contingent and specific way in which the status of "orthodox" and "heterodox" was accorded at a time when no clear orthodoxy existed. An individual such as W B Carpenter successfully constructed his claim to legitimacy for his work and ideas in the Principles of general and comparative physiology by a variety of strategies to influence how his work would be received and understood, while at the same time John Elliotson, despite his position as professor of the principles and practice of medicine at University College London, his experimental method and the initial support of prominent scientists, failed to achieve the same status for his mesmeric ideas. ${ }^{17}$ Mark Weatherall has emphasized the strategies of exclusion from hospital posts, medical schools, journals and societies which the threat of homœopathy provoked in mid-Victorian Britain, both because it attracted patients and because it offered an empirical and rational scientific basis for the advancement of medicine even though its medical theories

\footnotetext{
${ }^{13}$ Price, op. cit., note 7 above, p. 280.

"Counterhegemonic" is the highly useful term coined by Ramsey in Matthew Ramsey, 'Alternative medicine in modern France', Med. Hist., 1999, 43: 286-322, p. 289.

${ }^{14} \mathrm{See}$, for example, Kelvin Rees, 'Water as a commodity: hydropathy in Matlock', in Roger Cooter (ed.), Studies in the history of alternative medicine, Basingstoke, Macmillan, 1988, pp. 28-45. Richard Metcalfe, The rise and progress of hydropathy in England and Scotland, London, Simpkin, Marshall, Hamilton, Kent, 1913, pp. 171-90.
}

\footnotetext{
${ }^{15}$ P S Brown, 'Social context and medical theory in the demarcation of nineteenth-century boundaries', in W F Bynum and Roy Porter (eds), Medical fringe and medical orthodoxy, 1750-1850, London, Croom Helm, 1987, pp. 216-33, on pp. 223-30.

${ }^{16}$ Rees, op. cit., note 14 above, p. 30 .

${ }^{17}$ Alison Winter, 'The construction of orthodoxies and heterodoxies in the early Victorian life sciences', in Bernard Lightman (ed.), Victorian science in context, Chicago and London, University of Chicago Press, 1997, pp. 24-50.
} 


\section{James Bradley and Marguerite Dupree}

and therapeutics differed. ${ }^{18} \mathrm{~A}$ recent collection of essays points to the contrast between the sharp divide in the United States and Germany between homøopaths and regular practitioners, and the relative professional harmony in Canada where homœopathic practitioners can be viewed as regular physicians with a speciality in homœopathy. ${ }^{19}$ Elsewhere we have concentrated on the medical and social: identifying the medically qualified hydropathists in Britain and exploring the forces, particularly the social and financial opportunities the hydropathic institution offered and the practitioners' underlying need to diversify to make a medical living in this period, that pushed or spurred them into taking up the water cure compared with alternative medical opportunities. ${ }^{20}$ Also, James Bradley has examined orthodoxy, using hydropathy to reveal the contours of orthodoxy and show that orthodoxy was not fixed but rather was a process bound up with the formation of professional identity, analogous to the formation of national identity. ${ }^{21}$

Here we focus on hydropathy in order to develop a deeper understanding of its relationship to orthodoxy, concentrating on an explicitly medical account of hydropathy within the medical world view. In contrast to qualified homœopathists who challenged both received theoretical and therapeutic ideas, ${ }^{22}$ we find that hydropathic practitioners adhered to orthodox views of the body and disease, while abandoning received therapeutics, and we examine the process that enabled this to take place. Indeed, the connections between hydropathy and orthodoxy were closer than many of the contemporary medical critics of the system, and some of its advocates, admitted. For hydropathy, as practised by qualified medical practitioners, bore deeper similarities to the expectant and hygienic wings of medicine than it did to the other heterodoxies with which it is commonly associated. Its theoretical sources were often identical to the mainstream. Its physiology and pathology were derived from orthodox models of the body's relationship to health and illness, often using, as its authority, various interpretations of Justus Liebig's chemical physiology to justify its therapeutic regime. Furthermore, it attempted to produce an analogue to the orthodox materia medica, mapping the effects of hydropathic therapies onto

\footnotetext{
${ }^{18}$ Mark W Weatherall, 'Making medicine scientific: empiricism, rationality, and quackery in mid-Victorian Britain', Soc. Hist. Med., 1996, 9: 175-94, p. 181.

${ }^{19}$ See, among others: John Harley Warner, 'Orthodoxy and otherness: homeopathy and regular medicine in nineteenth-century America', in R Jütte, G Risse and J Woodward (eds), Culture, knowledge, and healing: historical perspectives of homeopathic medicine in Europe and North America, Sheffield, European Association for the History of Medicine and Health, 1998, pp. 5-30; Naomi Rogers, 'American homeopathy confronts scientific medicine', in ibid., pp. 32-64; J T H Connor, 'Homoeopathy in Victorian Canada and its twentieth-century resurgence: professional, cultural and therapeutic perspectives', in ibid., pp. 111-38.
}

\footnotetext{
${ }^{20}$ James Bradley and Marguerite Dupree, 'Opportunity on the edge of orthodoxy: medically qualified hydropathists in the era of reform, 1840-60' Soc. Hist. Med., 2001, 14: 417-37. We also surveyed the development of hydropathic establishments in Scotland, see: Marguerite Dupree, James Bradley and Alastair Durie, 'Taking the waters: the development of hydropathic establishments in Scotland 1840-1940', Bus. econ. Hist., 1997, 26: 426-37.

${ }^{21}$ James Bradley, 'Medicine on the margins: hydropathy and orthodoxy in reform era Britain', in Waltraud Ernst (ed.), Plural medicine, tradition and modernity 1800-2000, London, Routledge, 2002, pp. 19-39.

${ }^{22}$ Weatherall, op. cit., note 18 above, p. 192.
} 
those of the orthodox armamentarium. Thus, many hydropathists claimed their regime could reproduce the effects of drugs, bleeding, and almost all other forms of allopathic practice. And yet, for all the orthodox thought that underwrote the water cure, it remained a heterodox practice, not least because it challenged accepted forms of medical action and behaviour. In revealing this, we will suggest that a more nuanced conception of the epistemological constitution of orthodoxy is required-an understanding that does not bifurcate knowledge into two opposing camps. To achieve our aim we will analyse the medical views of the qualified hydropathists: they ran the majority of hydropathic institutions and produced the bulk of the theoretical literature. ${ }^{23}$ But first, we will attempt to describe the orthodoxy against which hydropathy has been placed.

\section{Whose Doxy was Orthodoxy? ${ }^{24}$}

It is unclear when the term "orthodoxy" was first applied to medicine, although we have found a reference to it in an 1846 Lancet editorial as a charge which opponents levelled against the Lancet "to denigrate the practice and practitioners of legitimate medicine". ${ }^{25}$ The editor was happy to accept the accusation, which reflected contemporary debates surrounding tractarianism. ${ }^{26}$ Although "orthodoxy" appears to have been a less common description during the 1840 s and 1850 s than "legitimate" or "scientific" medicine, by 1863 the hydropathic practitioner and proprietor of a famous establishment at Malvern, James Manby Gully, scathingly commented upon its use in medical discourse.

Where is the revelation on which to build the Orthodoxy? In the human body with its endless temperaments, constitutions and variations of morbid phenomena? Where exists the Council, Convocation, General Assembly, Conference, whatever the thing may be called, to pronounce upon Heterodoxy? And whence are its powers derived? And by whom acknowledged? Are we to have a medical parallel to the ecclesiastical divisions in the High Dose Church and the Low Dose Church? ${ }^{27}$

Gully's particular interests are barely masked by this extended religious metaphor. The proclaimed "orthodoxy", ironically reflecting the division within homœopathy,

\footnotetext{
${ }^{23}$ It should be noted that many unqualified hydropathists also accepted orthodox medicine's models of disease and the body, and drew on the accounts of qualified advocates. The difference between the accounts of the therapeutic rationale of hydropathy by qualified practitioners and an unqualified proponent, such as John Smedley, lay in style and organization. Bradley, op. cit., note 21 above, pp. 23-4.

${ }^{24}$ Bishop William Warburton (1698-1779) was reported to have remarked to Lord Sandwich, "Orthodoxy is my doxy; heterodoxy is another man's doxy".

${ }^{25}$ Lancet, 1846, ii: 568.

${ }^{26}$ Ibid., p. 567. For discussion of the etymology of medical "orthodoxy" and its links
}

with current disputes between the Oxford Movement and evangelicals over what constituted legitimate doctrine, see Bradley, op. cit., note 21 above, pp. 31-4. See also, John V Pickstone, 'Establishment and dissent in nineteenth-century medicine: an exploration of some correspondence and connections between religious and medical belief-systems in early industrial England', in W J Sheils (ed.), The church and healing: studies in church history, Oxford, published for the Ecclesiastical History Society by Basil Blackwell, 1982, pp. 165-89.

${ }^{27}$ James Manby Gully, A guide to domestic hydrotherapeia. The water cure in acute disease, London, Simpkin, Marshall, 1863, p. xi. 
was so varied that hydropathy could, therefore, be presented as no less legitimate than other therapies. In elaborating this point, his main concern lay not with the institutional organization of medicine per se, but the bonds between medical organization and medical knowledge. Despite his interests, Gully's observations were not obtuse: even in the 1860s, after the Medical Act of 1858 established the General Medical Council and the Medical Register, Clause 23 of the Act preserved the liberty of registered practitioners to practice whatever system of medicine they saw fit, and no single authority existed to enforce uniformity over a discipline that was fragmented by organizational, intellectual and social divisions.

What was true after the creation of the General Medical Council in 1858, was more so during the $1840 \mathrm{~s}$. Aside from the conflicts over the organization of medicine, sound and fury epitomized reform-era debates over medical theory and practice. The localized pathology of the solid tissues, fibres and nerves-in the British context a Cullenian tradition transformed by the morbid anatomy of Paris-competed with a rejuvenated humoral pathology. ${ }^{28}$ Compared to pathology or physiology, aetiology was relatively less important: while disease was perceived to arise from a combination of remote causes (miasmatic forces, heredity, mental state, heat, cold etc.), the orthodox physician tended to target treatment at the proximate cause (the underlying physical process of the disease itself). ${ }^{29}$ And while much play has been made of morbid anatomy's localizing impulse, the majority of physicians still conceived the body in holistic terms: the various organs (including the brain), nervous system and fluids intimately connected together in a systemic whole, where the malfunction of one part might affect many others. In therapeutics, some clung to the established "revulsive" regime, administering bleeding and high doses of potent chemicals. Others rejected this mode in favour of "expectancy" or hygienic methods, both of which emphasized the need for a non-invasive management of the patient's constitution using regimen and small doses of drugs. But acceptance or rejection of a particular therapeutic regime was not solely dependent upon belief in specific pathological or physiological principles. Indeed, different therapeutic rationales often led to the employment of identical therapeutic regimes.

To illustrate this last point, it is worth revisiting John Harley Warner's account of the Edinburgh bloodletting controversy. As late as the 1850s, the majority of Edinburgh medical men continued to defend bloodletting as a practice, while rarely using it. John Hughes Bennett, on the other hand, rejected it outright. The "conservative" contention was founded in the "change of type theory" that explained the decline of bloodletting using one of two reasons: firstly, inflammatory diseases had metamorphosed from a sthenic to an asthenic type; secondly, the constitution of the human body had transformed since the heyday of venesection in the $1830 \mathrm{~s}$. In either case, strengthening or stimulating therapies were more suitable than the

\footnotetext{
${ }^{28}$ Margaret Pelling, Cholera, fever and English medicine, 1825-1865, Oxford University Press, 1978 , pp. 16 and 145.

${ }^{29}$ Christopher Hamlin, 'Predisposing causes and public health in early nineteenth century medical thought', Soc. Hist. Med., 1992, 5: 43-70,
}

pp. 50-53; Andrew Cunningham, 'Transforming plague: the laboratory and the identity of infectious disease', in Andrew Cunningham and Perry Williams (eds), The laboratory revolution in medicine, Cambridge University Press, 1992, pp. 209-44, on p. 221. 
depletion caused by bleeding. Bennett, however, argued that venesection had never been appropriate: a belief underpinned by a combination of microscopical research and clinical observation. His "scientific" observations indicated the need for "restorative" rather than "depletive" treatment. Bennett's therapeutic plan was, nevertheless, remarkably similar to that advocated by those therapeutic sceptics who emphasized the healing power of nature. There the similarity ended. Supporters of "expectant" medicine were often hostile to the "clinical relevance of laboratory science", while Bennett's rationale derived from reductive principles rooted in microscopical observation. ${ }^{30}$ Thus, in this context, we have two divergent views of medical theory occupying the same therapeutic ground, and three contested therapeutic rationales.

Edinburgh was, by no means, an exception. The reform era was beset with debate-sometimes guarded, sometimes ferocious-about the efficacy of therapy, and the underlying reasons why one regime was more effective than another. The focus was often upon the role of the vis medicatrix natura. The dispute was not about the existence of the body's capacity to heal itself. Few, if any, practitioners would have denied its existence. Bennett, himself, was an ardent believer in the healing power of nature and framed explanations for the success of his method of curing phthisis in these terms. ${ }^{31}$ In general, disputes tended to be about the best means of deploying medical art in favour of nature.

During 1844, a debate occurred in the Lancet that illustrates the dimensions of this conflict. On the one side was a sceptical correspondent, Charles Mackin, who was convinced that modern medical science was fatally flawed by an unscientific therapeutic rationale. On the other was the Lancet itself. The background to both positions was a clearly expressed fear of the challenge posed by heterodoxy. Mackin believed that the practice of medicine had not kept pace with developments in anatomy, physiology and materia medica. His argument was threatening, for he presented a therapeutic relativism that completely undercut the foundations of professional medical practice. Recovery not only took place "under regular and professional treatment", it also occurred under other regimes, including hydropathy and homœopathy. ${ }^{32}$ While he was at pains to dissociate himself from "quack" practices, Mackin believed their success had less to do with active intervention and more with the body's natural capacity to heal itself. Therefore, according to Mackin, the "discerning and skilful physician ought solely to apply his art to the furtherance and fulfilment of nature's instructions". ${ }^{33}$

The Lancet despaired of this argument. The extensive leader put aside to counter this and other sceptical arguments denied that a rift had opened up between medical science and therapeutics. Therapeutics had improved in line with increased knowledge about the body and disease. At the same time, notwithstanding its robust defence

\footnotetext{
${ }^{30}$ John Harley Warner, 'Therapeutic explanation and the Edinburgh bloodletting controversy: two perspectives on the medical meaning of science in the mid-nineteenth century', Med. Hist., 1980, 24: 241-58, pp. 245-53.
}

\footnotetext{
${ }^{31}$ John Hughes Bennett, 'On the treatment of phthisis pulmonalis', Mon. J. med. Sci., 1850, 1 (n.s.): 401-14, p. 414.

${ }^{32}$ Mackin, Lancet, 1844 , i: $473-5$, on p. 474 see also comments by Mackin in ibid., p. 278.

${ }^{33}$ Ibid., p. 475.
} 
of modern therapeutics, the Lancet would not gainsay Mackin's belief in assisting nature: "the efforts of those who practise the healing art have ever been directed to an imitation of the spontaneous curative processes of nature ... that is to say, to assisting nature in the elimination of the morbific cause of disease". ${ }^{34}$

In this context, it is worth examining the therapeutic rationale put forward by the Lancet. "We have said ... that among the moderns, LOUIS is the model that should be looked for in the physician". ${ }^{35}$ This alliance with Louis brings us to the heart of the matter. The Lancet believed that what separated the modern scientific medical knowledge of the 1840s from previous times was a clearer perception of the natural history of disease, specifically through the identification of internal lesions at post mortem. In place, however, of exclusive schools like hydropathy there was a need for the cautious inductive reasoning exemplified by Pierre Louis' exhaustive collection of information. However, while the Lancet was prepared to support the inductive methodology of Louis, it rejected the therapeutic implications of his argument-the scepticism that characterized the approaches of many of his followers. Indeed, editorial after editorial thundered through the 1840s in support of active forms of intervention in disease.

As this all too schematic discussion of the Mackin controversy reveals, therapeutics were one of the most important battlegrounds of mid-nineteenth-century medicine. However much the Lancet protested to the contrary, the therapeutic gap-the space between pathology and physiology on the one hand, and therapy on the other - contained a void that was only just being filled by the clinical epidemiology emerging from the hospitals of Paris under the guiding tutelage of Louis. ${ }^{36}$ But for now, explanations of the effectiveness of therapy could be achieved only by the speculative linkage of pathology and therapy using systematic explanations. Thus novel physiological and pathological theories, for example Liebig's chemical physiology, were used as resources for justifying therapeutics, whether relatively entrenched-bloodletting and counter-irritation are examples-or emergent and contested, like hydropathy itself.

William Gregory's translation of Liebig's Animal chemistry, or organic chemistry appeared in 1842 to noisy acclaim. As Margaret Pelling and others have demonstrated, Liebigian theory rapidly became an important, if plastic, part of medical discourse. Indeed, Liebig was used to underline both new humoral and morbid-anatomical modes of physiological and pathological thinking. His idea that disease was a chemical process resulting from an imbalance of the respiratory, excretory, and secretory functions of the body $\mathrm{y}^{37}$ allowed commentators to rationalize their targeting of therapy at these physiological functions. A review in the Lancet, for example, used the theory to validate orthodox therapeutics. The reviewer focused upon Liebig's insistence that his chemical physiology explained, for the first time, the effectiveness of revulsive therapeutic techniques, particularly counter-irritation. In some circumstances, the reviewer noted, Liebig believed it was appropriate to use less violent

${ }^{34}$ Ibid., pp. $163-4$.

${ }^{35}$ Lancet, 1846, ii: 537.

${ }^{36}$ Bradley, op. cit., note 21 above, pp. 27-9.

\footnotetext{
${ }^{37}$ William H Brock, Justus von Liebig: the chemical gatekeeper, Cambridge University Press, 1997, pp. 203-14.
} 
and more conservative methods, mixing the active intervention (venesection) with a modified regimen (diet). More striking, in this passage, is the way the reviewer highlighted the compliments bestowed by Liebig upon the sagacity of orthodox practitioners: "[t]hese methods, the result of ages of experience, are such that the most perfect theory could hardly have pointed them out more acutely or more justly than has been done by the observation of sagacious practitioners" ${ }^{38}$ This was a selfcongratulatory synthesis. Here Liebig is a sober supporter of a sensible and, for the Lancet, acceptable therapeutics. To read this, they had been vindicated. And yet, as we will see, Liebig's text proved equally amenable to the rhetorical justification of hydropathy. Here was a scientific position that supported what both parties already knew to be true.

The mapping of Liebig's chemical physiology onto different medical regimes indicates the significance of the therapeutic gap to understanding reform era medicine. More than this, however, it suggests a need for a shift in historiographical focus away from medical theory towards medical action and behaviour. As Warner has indicated in the American context, therapeutics had a symbolic power not possessed by the epistemological elements of medical theory. ${ }^{39}$ This symbolic power is no surprise. Practitioners were judged by deeds, not thoughts. Cure involved the manipulation, either directly or indirectly, of the bodies (and minds) of their patients. In this respect, practitioners were what practitioners did. It was not a therapeutic rationale that cured or killed: it was the lancet, the bolus, the manner of the practitioner or the regimen, which the practitioner wielded, prescribed or carried out as part of the art of healing.

Gully's critique of "orthodoxy" occurred five years after the Medical Act had brought about organizational change. Theory and practice, however, remained fragmented and contested. If the term "orthodoxy", as applied to the medical profession, was of recent coinage, it was an ideological signpost that expressed a desire for unity where disunity existed. Orthodoxy was not a specific organizational or legalistic state. Rather, it was a process-dynamic and ideological-revolving around fluid conceptions of legitimate behaviour and knowledge. Thus, we need to address the ways in which hydropathy was both similar to and different from orthodoxy. To achieve this we must develop an understanding of how hydropathy was developed after its "discovery". We will, therefore, examine how Priessnitz's ideas were translated in a British context, before undertaking an analysis of the grounds on which the ultra-orthodox objected to the water cure.

\section{Solving the Paradox of Priessnitz: Priessnitz and his "Translators"}

The single greatest problem, and the single greatest opportunity, that a medicallyoriented hydropathy faced was the founder-figure, Priessnitz. The orthodox assault upon hydropathy had a simple first principle: it was impossible for an unmedical

\footnotetext{
${ }^{38}$ Lancet, 1841-2, ii: 485.

${ }^{39}$ John Harley Warner, The therapeutic perspective: medical practice, knowledge, and
} 


\section{James Bradley and Marguerite Dupree}

man to make a valid contribution to the field of medicine. The most famous British critique of Priessnitzian hydropathy was found in Robert Hay Graham's Graefenberg. Graham was convinced that the water cure was effective in a limited number of diseases, but his trip to Gräfenberg left him believing Priessnitz a charlatan, and the majority of his patients secondary syphilitics. His observations were soaked in xenophobia, attributing the enthusiasm for hydropathy to the perversity of the German character. His description of Priessnitz was equally scathing. Priessnitz, he claimed, had established an underground cadre of spies whose duty it was to cover up accidents and inconvenient deaths and root out unbelievers. Graham, demonstrating the fluidity of acceptable ideas in the period, used one of what current historians would call unorthodoxy to criticize another. He detected a shifty subject whose character was open to a phrenological exegesis that revealed the distinct criminal traits of "caution, secretiveness, acquisitiveness, firmness, and self-esteem". Graham was in no doubt that Priessnitz was at best an ignorant quack, at worst an illiterate impostor. ${ }^{40}$

Critics of hydropathy latched onto this account. The Lancet's reviewer claimed Graham's book was "the most merciless exposé of the Graefenberg fraud". The same reviewer recounted with gusto Graham's melodramatic report of a beautiful maiden's death, before agreeing with the claim that Priessnitz had plagiarized the British tradition of using cold water as a therapeutic agent. ${ }^{41}$ Discounting hydropathy on the basis of Priessnitz was a key Lancet strategy, and Graham's assault merely confirmed the journal's worst fears. According to an editorial writer in February 1844 , Priessnitz "scarcely knows the names of the diseases he treats". This "ignorance" revealed a paradox:

[i]t has always struck us as rather singular ... that the head oracle, who is totally ignorant of the nature and symptoms of disease, should see so clearly the indications for its treatment, the more so as the professional hydropathists repeat to satiety in their works that none but those who possess sound medical knowledge are fit to be entrusted with the management of the panacea. ${ }^{42}$

It was singular, because, with few exceptions, this was exactly what the qualified hydropathists were saying. A typical resolution of the paradox is found in the famous early hydropathist, James Wilson's account of Priessnitz. For hydropathy to be medically valid, it was essential that Priessnitz be represented as a unique example of inborn human genius: "Priessnitz is ... an extraordinary case; one of those isolated instances which occur so seldom in the history of man. Let not, therefore, other uneducated persons attempt to practise the Water Cure.... The power of genius is no rule for ordinary mortals." ${ }^{33}$ The solution, then, was to emphasize the providential wisdom of Priessnitz, and take it from there.

\footnotetext{
${ }^{40}$ Robert Hay Graham, Graefenberg: or, $a$ true report of the water cure, London, Longman, Brown, Green, and Longmans, 1844, pp. 3-19.

${ }^{41}$ Lancet, 1844, i: 701-2. Both Hay Graham and the anonymous reviewer were completely at ease with the contradiction between Priessnitz's
}

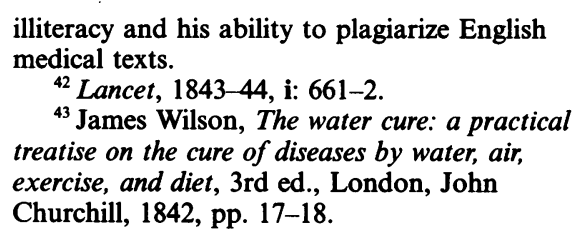




\section{An Epistemology of British Hydropathy, 1840-1858}

But what did "taking it from there" imply? Priessnitz left no written testimony, and he was reluctant to instruct others. Many physicians travelled to Silesia to study his methods, but he was unenthusiastic about medical men. He tolerated them, allowing them to observe his work. But he remained guarded to the point of paranoia, not least because he believed physicians were the progenitors of the iatrogenic diseases from which, he maintained, the majority of his patients suffered. Consequently, for lack of concrete description, practitioners adopting hydropathy had to translate the doings and occasional sayings of a peasant into a therapeutic system with a scientific rationale.

While even non-hydropathic practitioners were prepared to accept that Priessnitz was possessed of a "natural sagacity", ${ }^{44}$ none of the medically qualified hydropathic practitioners reproduced wholesale his theory and practice. As early as possible, their "translations" made incremental changes. Significantly, there was an active dissociation of his vulgar interpretation of humoral pathology, although not against humoral pathology per $s e{ }^{45}$ Aside from Priessnitz's pathological beliefs, there were concerns about some of his "wilder" ideas and practices, including his prohibition against wearing flannel, ${ }^{46}$ the type of food he insisted on serving his patients, ${ }^{47}$ and even his technique of wet-sheet packing. ${ }^{48}$ Furthermore, British exponents of hydropathy, while not dismissing it entirely, downplayed the importance of the visible crisis, which was the lynchpin of cure at Gräfenberg..$^{49}$ Finally, qualified hydropathists rapidly introduced new forms of treatment, including Gully's spirit lamp bath, the compressed air bath for treating phthisis, and the near wholesale acceptance of the Turkish Bath ${ }^{50}$ These modifications illustrate the extent to which medical practitioners, in the conceptual vacuum created by the lack of written testimony, were able to make their own interpretations of Priessnitz's cure. They were, nevertheless, modifications that occurred within the framework of established medical theory. This resulted in the reproduction of pre-existing divisions within medical discourse, particularly between humoral and localist pathology. To illustrate this we will look at the remoulding of hydropathy by Dr Edward Johnson and Gully.

Johnson was not the first to "translate" Priessnitz, but he was the first to explain the therapy in "scientific" terms. Beginning in general practice in a poverty-stricken part of Southwark where he wrote "as many as twenty thousand prescriptions in the year", Johnson subsequently established himself in a wealthier district where he discovered hydropathy. Following a trip to Gräfenberg in 1843, he took over a

${ }^{44}$ Prov. med. surg. J., 1842, p. 69.

${ }^{45}$ Charles Scudamore, $A$ medical visit to Gräfenberg, in April and May 1843; for the purpose of investigating the merits of the watercure treatment, London, John Churchill, 1843, p. 5; Wilson, op. cit., note 43 above, p. 42.

${ }^{46}$ Wilson, op. cit., note 43 above, pp. 46-7.

${ }^{47}$ Ibid., p. 19.

${ }^{48}$ Thomas $\mathrm{J}$ Graham, $A$ few pages on hydropathy, or the cold water system, London, $\mathrm{W}$ E Painter, 1843, p. 14.

${ }^{49}$ James Manby Gully, The water cure in chronic disease, London, John Churchill, 1846, p. 685; Edward Johnson, Hydropathy. The theory, principles, and practice of the water cure shewn to be in accordance with medical science and the teachings of common sense, London, Simpkin, Marshall, 1843, p. 207; also noted by Roger Cooter, 'Alternative medicine, alternative cosmology', in Cooter (ed.), op. cit., note 14 above, pp. 63-78, on p. 68 .

${ }^{50}$ Metcalfe, op. cit., note 14 above, pp. 73, 101-3, 126-41. 


\section{James Bradley and Marguerite Dupree}

hydropathic establishment in Surrey before moving to another near Birmingham, ${ }^{51}$ and in the 1850 s he finally established himself at the Bury, Malvern. His description of his conversion to hydropathy gives a lucid impression of both the motives a qualified practitioner might have for adopting hydropathy and how he might go about translating Priessnitz into a medically acceptable discourse. Having read Claridge's account, he was intrigued by the potential of the cure, not least because it seemed Priessnitz was "reducing to practice all the great principles" he (Johnson) had earlier described in his 1837 publication Letters to brother John. ${ }^{52} \mathrm{He}$ travelled to Silesia with three of his patients, arriving in November 1842 . His primary objective was to assess the veracity of Claridge's unmedical ramblings. Once his on-site observations had established the truth of hydropathy's effectiveness, Johnson had to explain, in scientific and medical terms, why it was so: "it will be observed that I have not referred to second-rate and obscure writers, nor have I raked up from Oblivion the crude opinions of a bygone age, but I have selected the most celebrated and the most modern-Liebig and Billing", ${ }^{53}$

The process is revealing. Johnson hears about Priessnitz, and is immediately able to see hydropathy's potential for reshaping therapy in a manner which tallies with his pre-existing beliefs. He travels to Gräfenberg. He observes Priessnitz. He confirms both the effectiveness of hydropathy and the correctness of his earlier beliefs. He is an experienced general practitioner, who knows about disease and its cure. ${ }^{54}$ More importantly, he understands that the principles and practice of hydropathy are deducible on scientific grounds from Liebig's physiological theories, and on medical grounds from Billing's therapeutics. Thus, notwithstanding its heterodox origin, hydropathy was congruent with contemporary scientific and medical thought. Johnson's efforts were, therefore, directed towards normalizing hydropathy within orthodox medical discourse. The intention was not to create a system which challenged accepted medical theory, rather to develop an analogue practice producing identical effects to its drug counterpart.

Johnson, himself, was a convinced neo-humoralist whose pathology placed greater emphasis upon general rather than local disease. He had alluded to these ideas in Letters to brother John, although, as its preferred reader was a layman, detailed descriptions of pathology were avoided. ${ }^{55} \mathrm{He}$ delineated more forcefully his pathological thinking in Hydropathy:

... it was formerly supposed that all diseases depend upon a morbid condition of the humors, or the presence of certain morbid matters in the blood, or other vital fluids. Morbid anatomy, however, has since proved that this is not the fact. ... But, although there are exceptions to the rule, it is now beginning to be admitted ... that there is more truth in the humoral pathology than medical philosophers have been willing to allow. ${ }^{56}$

${ }^{51}$ Ibid., pp. 77-80.

${ }^{52}$ Johnson, op. cit., note 49 above, p. v.

${ }^{53}$ Ibid., pp. vi-vii.

${ }^{54}$ Ibid., pp. xiii-xiv.

${ }^{55}$ Edward Johnson, Letters to brother John, on life, health, and disease, London, Saunders

and Otley, 1837, esp. pp. 212-13. Letters was originally published over twelve months as twelve separate letters in the Metropolitan Magazine.

${ }^{56}$ Johnson, op. cit., note 49 above, p. 217. 
He firmly believed that "local" disease, causing lesions in tissues, was merely the result of a "general" disease which assaulted the fluids of the body. ${ }^{57}$

A large section of Hydropathy was set aside to explain Liebig's formulation of the chemical basis of physiology and pathology.$^{58}$ As with orthodox practitioners and theoreticians, Liebig was manna to the medically-qualified hydropathists. Charles Scudamore, for example, elicited Liebig's half-hearted approval in a personal interview. ${ }^{59}$ Partly due to this, but mainly due to Johnson's efforts, Liebigian theory became a touchstone of British hydropathy. Hydropathy was published in 1843, a year after Gregory's translation of Animal chemistry. Liebig permitted, among other things, the expression of a functional view of health and disease congruent with Johnson's own construction of humoral pathology. In many cases, general breakdown was, therefore, attributable to the chemical processes outlined by Liebig. But Animal chemistry also provided him with a powerful rhetorical device: a scientifically respectable theory that explained the efficacy of the water cure and validated its use. Johnson had probably become acquainted with Liebig's ideas prior to his conversion to hydropathy and, assuming this, the chemist supplied him with mental scaffolding around which he could erect an interpretation of Priessnitz's success.

Johnson was not the only qualified hydropathist to use Liebig as an authority. Gully and Wilson drew on him to defend themselves against the accusation that hydropathy thinned the blood.$^{60}$ William Macleod, resident physician from 1846 at Ben Rhydding Hydropathic in Yorkshire, used Liebig's, and to a lesser extent Johannes Müller's, theory of nutrition to justify the dietetic regime of hydropathy. ${ }^{61}$ Given all this, and the humoral bent of Priessnitzian hydropathy, we might expect the majority of hydropathic practitioners to follow Johnson in his humoral ways but, with the exception of E G Martin, none did. ${ }^{62}$ Most came to hydropathy from the dominant pathological tradition of morbid-anatomy. Macleod "laboured with zeal in the pathological department of the Edinburgh Royal Infirmary for three years", undertook microscopic studies, assisted in post-mortems and went round the wards, examining every case of interest, the progress of diseases, varied phases and tendencies and effects of treatments. He concluded that "the practice pursued was erroneous, based on no settled principle, without science, and consequently ... not just erroneous but dangerous frequently undermining the constitution and hastening death", and he resolved "never to have to do with what is commonly called the Drug or Allopathic Practice, but to devote my energies to the study and teaching of Anatomy and Physiology" ${ }^{63}$ Gully's translation of Priessnitz is an equally extreme

\footnotetext{
${ }^{57}$ Edward Johnson, The domestic practice of hydropathy, London, Simpkin, Marshall, 1849, pp. 54-64.

${ }_{58}$ Johnson, op. cit., note 49 above, pp. 88-233.

${ }^{59}$ Scudamore, op. cit., note 45 above, p. 99.

${ }^{60}$ James Wilson and James M Gully, The dangers of the water cure, London, Cunningham and Mortimer, 1843, but reprinted in Gully, Water cure in chronic disease, 7th ed., 1856, London, John Churchill, pp. 666-8.

${ }^{61}$ Water Cure Journal, 1848, ii: 34-5; for another use of Liebig, see John Goodman,
}

Hydropathy, or the philosophy of bathing, London, William Horsel, c.1859, pp. 57-62.

${ }^{62} \mathrm{E}$ G Martin, Water treatment of gout and rheumatism, London, Longman, 1844, p. 7. For a rebuttal of humoralism see Wilson, op. cit., note 43 above, p. 44.

${ }^{63}$ William Macleod, A letter to Professor J. Y. Simpson President of the Royal College of Physicians concerning the resolution recently passed by that body in reference to the therapeutic practice commonly called homoeopathy, London, Edinburgh and Glasgow, 1851, pp. 2-3. 
example of this adherence to the dominant tradition of morbid anatomy. He believed that both acute and chronic diseases were the efforts of "the morbid organ or organs to throw off their disorder upon some less important organ or organs. Thus acute inflammation of the liver, stomach, or lungs, causes fever, that is, an effort to throw the mischief on the skin, the bowels, or the kidneys."64 The nervous system was central to his pathology. Like the vast majority of medical men, Gully adhered to the description of the system as two-tiered, divided between the "animal" and "organic" nerves. ${ }^{65}$ The "animal" nerves were those that related to sensation and volition, linking the brain, the spinal cord and the outer world. The "organic" nerves connected the internal organs, but were not productive of sensation. Rather, they were part of the "sympathetic" system which could, when an organ was infected with morbific matter, act as conduit for the spread of disease to other parts of the body.

This was, perhaps, as near consensus as hydropathists came over pathology. Thus Wilson, who was closely connected to Gully, followed this explanation of disease. ${ }^{66}$ More explicit was Thomas J Graham, author of Domestic medicine, who believed that in the majority of cases "[t]he alteration in the nervous system can alone account for it" ${ }^{67}$ But Gully went further, demonstrating that his theory derived its authority from François Broussais, for he was prepared completely to abandon the notion of "general disease":

... in truth, there is no such thing. All the organs of the body may give signs of diseased action, but there are invariably one or more parts whose malady originates all that we see.... [Y]et ... actions, may, and very often do, depend on a small patch of inflammation in the stomach, perhaps no larger than a half-crown, or even a shilling. ${ }^{68}$

Both Gully and Wilson had studied in Paris in the late 1820s when Broussais's doctrine was in its ascendance. Broussais was the reductionist ad absurdum: ${ }^{69}$ all disease was reducible to inflammation of the gastrointestinal tract (gastroenteritis), and all therapies to depletion (bleeding and leeching, combined with a near-starvation diet). ${ }^{70}$ Apart from translating Broussais in the mid-1830s, Gully testified elsewhere to the "acuteness and originality of the great man whose name the doctrines in question bear". ${ }^{71} \mathrm{He}$ did not reiterate his admiration for Broussais in his hydropathic works, but the bedrock of his pathological ideas proved immutable. Indeed, in The water cure in chronic disease, he referred back to his pre-hydropathic work, vigorously repeating the axiom that "death comes only by the viscera". ${ }^{72}$

\footnotetext{
${ }^{64}$ Gully, op. cit., note 49 above, p. 688.

${ }^{65}$ For a standard description, see W B Carpenter, A manual of physiology, including physiological anatomy for the use of the medical student, London, John Churchill, 1846, pp. 217-20.

${ }^{66}$ See James Wilson, The principles and practice of the water cure, London, John Churchill, 1854, passim.

${ }^{67}$ Graham, op. cit., note 40 above, p. 11.

${ }^{68}$ Gully, op. cit., note 49 above, p. 3.
}

\footnotetext{
${ }^{69}$ Michel Foucault, The birth of the clinic. An archaeology of medical perception, London, Tavistock, 1976, pp. 184-92.

${ }^{70}$ For America, see Warner, op. cit., note 39 above, pp. 123-4.

${ }^{71}$ James M Gully, The simple treatment of disease deduced from the methods of expectancy and revulsion, London, John Churchill, 1842, p. 25.

${ }^{72}$ Gully, note 49 above, p. 11; for first use of this axiom see ibid., p. 190.
} 


\section{An Epistemology of British Hydropathy, 1840-1858}

Broussais's pathology was contested. By the mid-1830s, his system had fallen into disrepute, rejected by his students and discredited by his treatment of the 1832 cholera outbreak as acute gastroenteritis. ${ }^{73}$ Thomas Hodgkin, for example, criticized Broussaisism as "the 'soi-disant physiological doctrine,' whose disciples 'will see nothing but inflammation everywhere'" ${ }^{74}$ Furthermore, an editorial in the Lancet elevated Broussaisism to the status of one of the monistic systems that had assailed orthodoxy. ${ }^{75}$ Notwithstanding these attacks, Broussais was not beyond orthodoxy. His impact outlasted his brief vogue due to his emphasis, albeit over-emphasis, upon the localization of disease. ${ }^{76}$ As with Johnson's humoralism, it would be wrong to perceive Gully's adherence to Broussais as a sign of quackery. Indeed, a short review of Gully's Simple treatment of disease (1842) in the Lancet was full of praise for the work, despite its acknowledgement of Gully's adherence to the discredited Frenchman. ${ }^{77}$

Analysis of Gully's written work before his conversion to hydropathy reveals that, like Johnson, his views on pathology and physiology essentially remained unchanged. Thus, his co-authored monograph with Wilson, The dangers of the water cure (1844), and his own The water cure in chronic disease (1846) described disease in similar terms to The simple treatment of disease and even An exposition of the symptoms, essential nature and treatment of neuropathy, or nervousness (1837). Each focused upon the relationship between disease and the nervous system. Each weighted its arguments towards the perspective that disease was more often than not the result of lesions in the gastro-intestinal tract. Unbroken, too, was Gully's own interest in nervous dyspepsia. All that appeared to change was his mobilization of new allies like Liebig combined with a shift from using the conservative therapy, which emphasized regimen as well as the occasional use of drugs and bleeding, to out-andout hydropathy.

As with orthodox therapeutics, adherence to hydropathic practice was not a function of a specific pathological or physiological viewpoint. A belief in humoral pathology made it no more likely that a practitioner would adopt expectant over revulsive therapeutics, or, indeed, hydropathy over both. The reason for this was that, on the theoretical level, the difference between humoral pathology and the pathology of lesions was one of first causes. Neither party entirely discounted the existence of either local or general disease. Rather, it was a question of precedence. For Johnson, the functioning of the nervous system was affected by changes in the blood. Metastasis along the pathways of the nervous system implied that debility in one organ could lead to debility in another. For Gully, functional disturbance was invariably the result of a local disorder, although local disorder might itself be the product of general lowering in tone of the vital actions of the nervous system. None

\footnotetext{
${ }^{73}$ Charles Coulston Gillispie (ed. in chief), Dictionary of scientific biography, 16 vols, New York, Scribner, 1970-80, vol. 2, pp. 507-8.

${ }^{74}$ Quoted in Russell C Maulitz, Morbid appearances: the anatomy of pathology in the early nineteenth century, Cambridge University Press, 1987, p. 205.
}

\footnotetext{
${ }^{75}$ Lancet, 1846, ii: 537.

${ }^{76}$ It was for this reason that Foucault believed that Broussais' doctrine was a defining moment in the birth of the clinic. See Foucault, op. cit., note 69 , p. 192.

${ }^{77}$ Lancet, $1841-42$, ii: 794.
} 


\section{James Bradley and Marguerite Dupree}

the less, while one perspective was humoral and the other anatomical, both were holistic in physiological orientation. They were premised upon the idea that the body was an interconnected system, where the actions of the tissues and fluids were intimately bound together, and where the health of the body was determined by the environment through which it moved and the mental stresses to which it was subjected.

Like the vast majority of reform-era medical practitioners, hydropathists held fast to the rhetoric of induction, while interpreting disease and the body through a deductive framework. Rather than practising the Baconian project, they justified hydropathy by resorting to theoretical positions held a priori. Gully and Johnson, for example, appeared to derive their faith in hydropathy from entrenched pathological and physiological positions. To them, the water cure's unquestionable ability to cure disease demanded explanation. But Priessnitz's crude speculative theories needed to be reshaped using the contemporary medical theory which structured their own worldviews. Thus Priessnitzian therapy was mapped onto Liebig's biological chemistry or Broussais's pathophysiology. As much as Gully and Johnson reaffirmed induction by explaining Priessnitz's success as a product of his powers of observation, it is clear that their respective views were shaped by their favoured networks. And being part of the wider culture of the medical profession, educated in its language and mores, they shared, along with most medical practitioners, a perception of the body's relationship to health and disease, which was materialistic yet holistic, organic yet vitalist. As such, medically-qualified hydropathists were only vitalists, localists, holists, or humoralists to the extent that medical discourse itself was vitalist, localist, holistic or humoralist.

So steeped were hydropathic practitioners in the orthodox medical worldview that they attempted to develop a materia medica where the effects of hydropathic techniques were made equivalent to their drug counterparts. The third part of Johnson's Hydropathy was an extended commentary on the connection between Liebig's theory and Billing's First principles of medicine. Johnson here demonstrated that there was congruity between his favoured subjects: "it will be observed how beautifully Liebig's theory of life (as far as it regards morbid actions) and Billing's theory of disease, reciprocally support each other-and both, the principles of the water cure". ${ }^{78}$ Billing had simplified the practice of medicine by reorganizing the materia medica. He maintained the effects of all drugs could be reduced to four actions: stimulant, tonic, sedative and narcotic. ${ }^{79}$ Johnson illustrated that the different actions of water, however administered, could achieve each of these effects.

Johnson was not alone in arguing this. John Forbes, erstwhile translator of Laënnec and editor of The British and Foreign Medical Review, noted in a review of hydropathic works that Priessnitz "has modified the application of water, and some very few other means, in a manner so ingenious as to render them no imperfect nominal substitute, at least, for most of the drugs in the pharmacopœpia". ${ }^{80}$ Likewise,

\footnotetext{
${ }^{78}$ Johnson, op. cit., note 49 above, p. 235.

${ }^{79}$ Archibald Billing, First principles of medicine, London, Thomas and George Underwood, 1831, see esp. p. 44.
}

${ }^{80} \mathrm{Br}$. for. med. Rev., 1846, 18: 437. 
all qualified hydropathists spoke about the effects of the different hydropathic treatments in analogous terms to drugs. This was exemplified by John Goodman's materia medica that compared hydropathic with allopathic techniques. In it he listed more than 118 different modes of using water, both general and local, all of which could be graded by time and temperature. This was followed by a tabular arrangement illustrating that drugs had their equivalent in the "various applications of water". ${ }^{81}$ The significance of the hydropathic materia medica lies in the conception that its physiological and therapeutic effects were analogous to allopathy. In short, it completed the mapping process. Priessnitz's system had been translated from a heterodox language, which in all senses rejected "orthodox" medicine, into a medical language, which rejected the predominant mode of therapeutics alone.

\section{Diverse Hydropathists}

On the level of theory, the distance between the hydropathists and the allopathists was small. Hydropathy used water to induce the same physiological and therapeutical effects in the same disease situations. In this respect, it was solely a critique of the poisonous nature of drugs, not the specific effect they had on the organism. Furthermore, many of the qualified hydropathists would not, in principle, have rejected either Louis' programme of testing the efficacy of cure, or the dominant mode of experimentation in testing the physiological effects of materia medica. The latter, in particular, is implied in the University of Edinburgh MD thesis submitted by William Meikle (1857), soon to become a practitioner at Lochhead Hydropathic (Aberdeen), entitled 'On some of the actions and uses of water as a therapeutic agent'. Despite barely mentioning hydropathy, the spirit of the water cure pervades the document. More importantly, in its final stages he launched a scathing attack upon the shoddy experimental methods of another hydropathist.

Meikle dissected an article by Dr Howard Johnson, son of Edward Johnson, entitled 'Research into the effects of cold water on the human body \&c.' ${ }^{82}$ This professed "to be an exact account of ... [the wet sheet's] action on the pulse and the respiration in health". Johnson claimed that by applying the wet sheet he could induce the pulse of a healthy man, who had just taken "gentle exercise", to fall rapidly. Meikle, however, revealed that Johnson's methods were flawed. He argued firstly that Johnson was sliding dangerously towards quackery, particularly in his enthusiasm and "glorification of a special method of cure". This prevented him from taking the precautions that "any man with an ordinary medical education seeking truth" would have taken. Meikle, therefore, deployed the rhetoric of anti-quackery against Johnson, and thus sided himself with the angels of orthodoxy. Meikle demonstrated secondly that Johnson grossly exaggerated the effects of the wet sheet, for he had failed to take into account what would have occurred had the wet sheet not been used. Meikle, with the aid of a "fellow student", ran his own experiment.

\footnotetext{
${ }^{81}$ Goodman, op. cit., note 61 above, pp. 135-48.

${ }^{82}$ Edward Johnson, whose work has been examined in detail during this paper, had three
}

sons who became hydropathists, Howard being one of them. Metcalfe, op. cit., note 14 above, p. 81 . 
Having both partaken in "gentle exercise" they lay horizontally upon the floor just as a patient wrapped in a wet sheet might have lain. Their pulses fell by an average of 27.7 beats per minute, a better result than Johnson had attained with the wet sheet! Meikle pointed out that his own experiment was rough-and-ready, leading only to an approximate result. But, he maintained, it was certainly more scientific than Johnson's effort. ${ }^{83}$

Meikle concluded by commenting that the "blunder" was the result of "knavery or of ignorance", either of which was enough to convict Johnson of quackery. There remained, however, a lack of reliable information on the effects of the wet sheet. Such data was not to be provided by the strong assertions published in works "intended chiefly for the popular ear", because these were "not supported by the kind of evidence which a medical enquirer seeks and is entitled to expect". Here he was referring to the popular hydropathic manuals produced by the likes of Gully. He did, however, believe that these and other accounts provided circumstantial evidence for the sedative and calmative actions of the wet sheet. Furthermore, he believed that J H Stallard's work on fever and the wet sheet in Leicester Infirmary, ${ }^{84}$ had provided a level of detail and accuracy that was medically acceptable, and this went some way to demonstrating its therapeutic utility.

What is striking about Meikle's account is that it blends hydropathic methods seamlessly into the discourse of orthodox experimentation. But we can measure the closeness between the water cure and orthodoxy in other terms, specifically by analysing the attitudes of hydropathists towards drugs and other forms of therapy, illustrating that the therapeutic distance between many hydropathists and the Lancet was often closer than either party would have admitted. Johnson, for one, could see the issue clearly. "The difference", he said, "between drug treatment and the water treatment is this: that the latter strengthens while it cures. The former weakens while it cures." ${ }^{\prime 85} \mathrm{He}$ was implying that the problem with drug treatment was that the introduction of noxious substances into the body excessively irritated the stomach.

As Brown has indicated, attitudes to the use of drugs varied among hydropathic practitioners. ${ }^{86}$ Johnson was happy to use them alongside hydropathic methods. Indeed, he expended much effort in the reconciliation of the two regimes, while indicating that often drug treatment was more effective than its water-based counterpart. ${ }^{87}$ There were others who shared this opinion, particularly Graham. ${ }^{88}$ Even Gully and Wilson, often painted as out-and-out exclusivists, were not against drugs per se. On the face of it, their comment that it was an "egregious error ... to carry on a system of drug medication simultaneously with the treatment by water"89 appears unequivocally opposed to drugs. The adverb "simultaneously" goes a long way, however, towards modifying what might otherwise appear an exclusive position.

\footnotetext{
${ }^{83}$ William Meikle, 'On some of the actions and uses of water as a therapeutic agent', unpublished MD dissertation, University of Edinburgh, 1857, pp. 43-4.

${ }^{84}$ Br. for. med. Rev., 1847, $23: 269$.

${ }^{85}$ Johnson, op. cit., note 49 above, p. 70 .
}

\footnotetext{
${ }^{86}$ Brown, op. cit., note 15 above, pp. 224-6.

${ }^{87}$ Johnson, op. cit., note 49 above, p. xiv.

${ }^{88}$ Graham, op. cit., note 40 above, p. 4.

${ }^{89}$ Wilson and Gully, op. cit., note 60 above, p. viii.
} 
Elsewhere, Gully confirmed this standpoint by stating "let it not be supposed that I hold with exclusiveness as regards any system of treatment", ${ }^{90}$ Gully's rhetoric was aimed "against the spirit of system", a position implicitly shared by the majority of medically qualified hydropathists in their equivocality towards drugs. ${ }^{91}$

A rhetorical nod towards the rejection of systems in favour of eclecticism can be further seen in the attitude of hydropathists towards homœopathy. Brown has noted that hydropathists were also attracted to Hahnemann's system. ${ }^{92}$ This is partly true. Gully was in two minds, suggesting it was occasionally a useful adjunct to the water cure. $^{93}$ Malvern hydropathist, J L Marsden had been studying homœopathy in Austria when he first encountered word of Priessnitz's deeds. ${ }^{94}$ Nevertheless, most qualified hydropathists eschewed homoopathy. Indeed, they were more likely to prescribe allopathic drugs than infinitessimals. William Macleod was, however, one of the exceptions-not just in his use of homœopathy, but because he was a genuine eclectic. Originally an editor of the Water Cure Journal, he introduced several articles and editorials on homøopathy. For this sin he was forced to resign, ${ }^{95}$ but continued to advocate and to use his own version of "rational" and "eclectic" therapy, which combined the water cure, homœopathy, allopathy, and medical gymnastics derived from the Swedish Ling system. ${ }^{96}$ He had "no desire to join any sect; instead, his intention was to work out his "own views, to assume no name and to avoid all dogmatism", and eschewing the limitations of private practice in Edinburgh, he saw the post as physician at the new purpose-built hydropathic establishment at Ben Rhydding as offering the possibility of "testing opinion" in the course of treating the same large number of cases as in hospital practice and thus providing "rare opportunities ... for the development and promulgation of Truth ... absolutely free from control and irrespective of sect or party". ${ }^{97}$

Significantly, unlike qualified homœopathists, the hydropathists did not attempt to unite within a professional organization. There was no hydropathic equivalent of the British Homœoopathic Association which ministered to the interests of qualified homœopathists. ${ }^{98}$ Indeed, the fitful attempt and failure after three short years to make the Water Cure Journal a forum for discussion illustrates the broad church of the hydropathists. Aside from ascribing to a rhetoric of hydropathy and operating within the same market segment, there was little that bound them together-like other sectors of medical practice, the range of therapies carried out were more diverse than the theory that underpinned their use.

\footnotetext{
${ }^{90}$ Gully, op. cit., note 49 above, p. ix.

${ }^{91}$ See, for example, Rowland East, Results of the water cure, Glasgow, George Gallie, 1848, pp. 5-6; John Harley Warner, Against the spirit of system: the French impulse in nineteenth-century American medicine, Princeton University Press, 1998, pp. 224-8.

${ }_{92}$ Brown, op. cit., note 15 above, p. 226.

${ }^{93}$ Gully, op. cit., note 49 above, pp. 65-7.

${ }^{94}$ Water Cure J., 1848, 1: 4-5.
}

\footnotetext{
${ }^{95}$ Water Cure J., 1849, 18: 1-2.

${ }^{96}$ William Macleod, Directory of Ben Rhydding with a chapter on the water cure and homoeopathy, London, Charles Gilpin, 1852, pp. 33-6.

${ }^{97}$ Macleod, op. cit., note 63 above, pp. 3-6.

${ }^{98}$ See Glynis Rankin, 'Professional organisation and the development of medical knowledge: two interpretations of homœopathy', in Cooter (ed.), op. cit., note 14 above, pp. 46-62; Weatherall, op. cit., note 18 above, p. 181.
} 


\section{James Bradley and Marguerite Dupree}

\section{Gentlemen Behaving Badly?}

Regarding the medically qualified hydropathists, Rees has commented that because hydropathy's “leading theorists and practitioners of the 1830s and 1840s were qualified physicians ... the response of official medicine to hydropathy was often characterized more by mild circumspection than outright hostility". 99 The response was, however, often far removed from "mild circumspection", and frequently exhibited "outright hostility". Examining the range of responses allows us to assess more clearly the complex relationship between hydropathy and orthodox medicine. Thus, for example, the Lancet and, to a slightly lesser degree, the Provincial Medical and Surgical Journal, often reacted with prejudice. Others were more circumspect. But whatever these reactions consisted of, they reveal that the main problem with hydropathy lay in perceived ethical and behavioural abuses by its practitioners.

Of all the critics of hydropathy it was the Lancet which was most voluble, as it "strove to defend and strengthen those who occupy ... posts in the ... less wealthy walks of medical practice". ${ }^{100}$ On the most basic level, it merged hydropathy with homœopathy, mesmerism and other "fringe" medicines in a defensive rhetoric against the threat of "quackery" to the incomes and status of general practitioners. ${ }^{101}$ Here, any therapeutic qualities possessed by water were swiftly forgotten. Aside from this, many specific accusations were levelled against hydropathy and its practitioners. Firstly, it was noted that the doctrine was hardly new-the use of waters internally and externally being widely understood and frequently used within the profession. ${ }^{102}$ Critics also accused qualified hydropathic practitioners of advertising their wares by "puffing" their own establishments and cures. ${ }^{103}$ Some were undoubtedly "guilty" of this charge, particularly Macleod whose pamphlets often contained the tariff for Ben Rhydding. ${ }^{104}$ Others were more careful, dissociating their practice from commercial advertisement. Nevertheless, the behaviour of the few tarred all hydropathic practitioners with the same brush. Even those that eschewed promoting their own ventures, but wrote popular textbooks on the subject, ran the risk of alienation from the profession. For popular medical writing itself sat upon the cusp of respectable behaviour, usually the resort of physicians who had rejected general practice but had not been able to establish themselves as élite physicians. Hydropathists, therefore, breached the ethics which the Lancet and others were striving to impose on the profession, thus removing them from the norms and values of general practice.

Those hostile to hydropathy also maintained it was dangerous, publishing letters revealing the death of patients under the cure. The dangers of the water cure were proved to the Lancet by the death of Sir Francis Burdett, who had "paid the final tribute to nature" following hydropathic treatment, while Charles Hastings provided early revelations of the dangers of hydropathy for the Provincial Medical and Surgical

\footnotetext{
${ }^{99}$ Rees, op. cit., note 14 above, p. 30.

${ }^{100}$ Lancet, 1846, ii: 567.

${ }^{101}$ See, for example, ibid., pp. 567-8.

${ }^{102}$ Lancet, 1842-43, i: 687.

${ }^{103}$ See the criticisms levelled by a reporter against James Wilson, Lancet, 1841-42, ii:
}

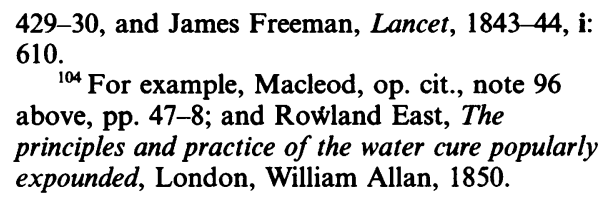


Journal. ${ }^{105}$ Later instances included the reporting of the celebrated manslaughter charge brought against the unqualified James Ellis resulting in the now famous editorial rebranding of the water cure as the "water death". ${ }^{106}$ Nevertheless, all qualified hydropathists who cared to comment on the issue insisted that only medical men were effective and safe practitioners. Thus they asserted professional authority over unqualified practitioners. They were also happy to concur with the Lancet's assessment of the dangers of the water cure, but only to emphasize the importance of its being carried out under qualified supervision.

The most important and biting criticism aimed against hydropathy, was however, its status as a monistic system of cure that excluded all other therapeutic regimes. Indeed, orthodox commentators were prepared to defend the use of water in therapy, as long as it did not slip into exclusiveness:

... the means of treatment which constitute hydropathy, considered as a portion of our therapeutical arsenal, are powerful medical and hygienic agents, but can only be adopted as a panacea for all diseases by the ignorant public, or by such medical men as wish to raise their fortunes on the credulity of others. ${ }^{107}$

More soberly, the Provincial Medical and Surgical Journal, commented "[i]t is its adoption ... to the exclusion of all other remedies, which we chiefly deprecate and condemn". ${ }^{108}$ This was an extremely harmful criticism, and one the rhetoric of the qualified practitioners had done much to generate. As we have seen, many practised eclecticly, and few had abandoned allopathy outright. But, in putting their case before the public-no doubt in an effort to promote their position within the market - they presented hydropathy as a more monolithic body of knowledge and practice than it actually was.

The sometimes virulent, sometimes muted reaction to hydropathy should be understood in terms of medical action. As such, it constitutes part of the debate over the proper behaviour of the qualified medical practitioner and his management of disease. Hydropathy, therefore, presents a fundamentally different case to homœopathy, and is more closely comparable with debates over therapeutic nihilism and expectant treatment, like that between Mackin and the Lancet. On the level of epistemology, hydropathy could barely be differentiated from orthodoxy. On the levels of representation and action, it was, however, another matter. In The therapeutic perspective, Warner describes the link between the professional identity of medical practitioners and their therapeutic practices. Commenting, in the American context, on the rapid transformation of pathological and physiological theories, he says "[e]pistemologies lacked the symbolic power invested in such emblems of the regular profession as bloodletting; thus the abrupt inversions of rationalism and empiricism were not intrinsically threatening to the profession in the way the prospect of revolution in principle or practice was" ${ }^{109}$ The British context was, of course, different to America. The Apothecaries Act of 1815 had gone a short distance towards

${ }^{105}$ Lancet, 1843-44, i: 610; Prov. med. surg. J., 1842, 1: 491-2; 1842-43, 5: 73-5, 149-50, 328-9; 1843, 6: $345-7$.

${ }^{106}$ Lancet, 1846, i: 661, 666-7, 707, 711.
${ }^{107}$ Lancet, 1843-44, i: 695.

${ }^{108}$ Prov. med. surg. J., 1842, ii: 50.

${ }^{109}$ Warner, op. cit., note 39 above, p. 6. 


\section{James Bradley and Marguerite Dupree}

regulating the profession, at least in England and Wales. Neither was the threat from sectarian practitioners so great, although many within the medical community felt threatened by irregulars and sectarians, particularly from the challenge of homœopathy. But where homœopathy, to varying degrees, challenged both the theory and practice of legitimate medicine, hydropathy as practised by qualified practitioners merely launched small sorties on therapy.

If, then, hydropathy existed as a shadow of orthodoxy, it was so by dint of the rhetorical constructions of both its advocates and opponents. It was in the interests of both parties to paint it as a more heterodox system than it actually was. From the point of view of the qualified hydropathist, it was necessary to secure a market niche by differentiating the water cure from other forms of medicine. Inevitably this led to breaches of professional etiquette. For their critics, the transgression of ethical boundaries signified the qualified hydropathist's most venal sin—the abandonment of acceptable medical action. 